doc. dr. sc. Mirjana Hladika

Ekonomski fakultet Sveučilišta u Zagrebu, Republika Hrvatska

mhladika@efzg.hr

Ivana Valenta, mag. oec.

Ekonomski fakultet Sveučilišta u Zagrebu, Republika Hrvatska

ivalenta@efzg.hr

\title{
INTEGRIRANO IZVJEŠTAVANJE - NOVA PLATFORMA KORPORATIVNOG IZVJEŠTAVANJA
}

Pregledni rad

\section{Sažetak}

Tržište se danas kontinuirano i ubrzano razvija i mijenja. Svijest o društvenoj odgovornosti, zaštiti okoliša i ljudskih prava postaje sve veća i izraženija, informatička tehnologija galopirajući napreduje i razvija se, klimatske promjene i njihovi učinci su evidentni. Takvi trendovi na suvremenom tržištu potaknuli su promjene u korporativnom izvještavanju. Sve više se naglašava važnost $i$ značajnost integriranog izvještavanja naspram tradicionalnog financijskog izvještavanja. Informacijske potrebe investitora, kreditora i ostalih interesnih skupina za svrhu donošenja poslovnih odluka, a prvenstveno odluka o investiranju i financiranju, nadilaze financijske informacije koje su prezentirane u financijskim izvještajima. Kako bi različiti stakeholderi mogli vrednovati, odnosno procijeniti poslovanje poduzeća, potrebne su im različite informacije kojima se dobiva šira slika o poslovanju poduzeća. Financijski izvještaji pružaju informacije o financijskom položaju, financijskoj uspješnosti i novčanim tokovima poduzeća koji su rezultat prošlih poslovnih odluka i odnose se na prošla razdoblja. Investitori zahtijevaju informacije kojima će procijeniti zarade i novčane tokove poduzeća u budućem razdoblju, odnosno razdobljima. Takve procjene su moguće ako se investitorima prezentiraju informacije o poslovnom modelu poduzeća, strategiji i rizicima kojima je poduzeće izloženo te načinu upravljanja poduzećem. Na temelju tih informacija stakeholderima se omogućava procjena kapaciteta poduzeća za stvaranjem održive vrijednosti u kratkom, srednjem i dugom roku, odnosno kako će poduzeće generirati održivu vrijednost u okruženju u kojem posluje. Objavljivanjem nefinancijskih informacija, uz financijske informacije, jača se transparentnost poduzeća, a korisnici stječu višu razinu povjerenja u poslovanje i perspektivu poslovanja takvih poduzeća. Danas se takve nefinancijske informacije počinju koherentno objavljivati u integriranim izvještajima zajedno s financijskim informacijama. Svrha i cilj ovog rada je istražiti da li i u kojoj mjeri kotirana društva na Zagrebačkoj burzi, i odabranim svjetskim burzama, 
objavljuju integrirane izvještaje. Uz to, cilj je istražiti koji se okvir primjenjuje za pripremu nefinancijskih izvještaja.

Ključne riječi: integrirano izvještavanje, korporativna transparentnost, održiva vrijednost, društvena odgovornost

JEL: M40, M41

\section{UVOD}

Tijekom vremena sve se više razvija svijest o potrebi zaštite okoliša, brizi o društvenoj zajednici i zaštiti ljudskih prava, te općenito o društvenoj odgovornosti poduzeća pri obavljanju poslovnih aktivnosti, stoga i korisnici iskazuju sve veći interes za informacijama upravo o tom segmentu poslovanja poduzeća. Razumijevanjem načina poslovanja poduzeća u sadašnjosti i poznavanjem strategije poduzeća stakeholderi mogu generirati zaključke o potencijalnoj održivosti ili neodrživosti poslovanja poduzeća u dugom roku, sposobnosti poduzeća da generira zarade i novčane tokove i u budućnosti.

U cilju zadovoljenja informacijskih potreba različitih korisnika, na nacionalnoj, regionalnoj i globalnoj razini sve je veći broj poduzeća koja sastavljaju i pripremaju integrirani izvještaj, ili objavljuju nefinancijske informacije u okviru zasebnog, samostalnog izvještaja. Objavljivanjem dodatnih nefinancijskih informacija povećava se kvaliteta korporativnog izvještavanja i transparentnost poduzeća, a korisnici stječu višu razinu povjerenja u poslovanje i perspektivu poslovanja takvih poduzeća.

Integrirano izvještavanje je proces koji podrazumijeva financijsko i nefinancijsko izvještavanje u jednom izvještaju - integriranom izvještaju. Prema tome, integrirani izvještaj je izvještaj koji se treba javno objaviti i koji treba biti dostupan zainteresiranim korisnicima, a u njemu bi trebale biti integrirane financijske $\mathrm{i}$ nefinancijske informacije o poduzeću. Objavljivanje šireg obuhvata informacija o poduzeću omogućava korisnicima tih informacija donošenje kvalitetnijih poslovnih odluka, prvenstveno o investicijama u određena poduzeća i financiranju. Stakeholderi žele imati informacije na temelju kojih mogu razumjeti poslovni model, strategiju, rizike (uključujući i rizike održivosti) i sustav upravljanja poduzećem. Razumijevanjem navedenih kategorija stakeholderima se pomaže u procjeni kapaciteta poduzeća da stvori održivu vrijednost u kratkom, srednjem i dugom roku. 
U suvremenim uvjetima poslovanja odgovorno ulaganje (investiranje) zasniva se na ulaganjima koja će rezultirati pozitivnim društvenim, okolišnim i ekonomskim ishodima kao i ostvarivanjem zarada, što predstavlja značajan odmak od „tradicionalnog" ulaganja koje je primarno bilo usmjereno na ostvarivanje zarada investitora (ekonomske povrate) (Couldridge, 2014). Dakle, cilj je da investicija doprinese ne samo zaradama investitora, već istovremeno mora generirati pozitivne društvene, okolišne i ekonomske ishode.

Rezultati istraživanja koje je provelo Međunarodno vijeće za integrirano izvještavanje (engl. International Integrated Reporting Council - IIRC) pokazali su da je tijekom posljednjih nekoliko godina na globalnoj razini značajno povećan broj poduzeća koja su započela s objavljivanjem integriranih izvještaja te da usvajanje integriranog izvještavanja dovodi do boljeg razumijevanja načina na koji poduzeća stvaraju vrijednost (IIRC, 2014). Nadalje, rezultati istraživanja koje je proveo KPMG (2015) pokazuju da među zemljama čija poduzeća objavljuju integrirane izvještaje prvo mjesto zauzima Južnoafrička Republika u kojoj čak 91 poduzeće objavljuje integrirane izvještaje. Drugo mjesto dijele Nizozemska i Španjolska u kojima je objavljeno po 27 integriranih izvještaja, treće mjesto pripada Japanu u kojem je objavljen 21 integrirani izvještaj, dok je na četvrtom mjestu Švedska gdje je 13 poduzeća objavilo integrirane izvještaje. Također, ovim istraživanjem utvrđeno je da četiri zemlje u razvoju (Indija, Indonezija, Malezija i Južnoafrička Republika) imaju najvišu stopu izvještavanja o društvenoj odgovornosti promatrano na svjetskoj razini.

U tom kontekstu, cilj ovog rada je analizirati i sistematizirati pregled literature koji obuhvaća problematiku integriranog izvještavanja koja je zasad još uvijek nedovoljno zastupljena u literaturi s posebnim osvrtom na međunarodne okvire koji se koriste kao temelj za pripremu i objavu nefinancijskih informacija. Nadalje, cilj ovog rada je istražiti način objavljivanja nefinancijskih informacija, odnosno da li se nefinancijske informacije objavljuju u obliku samostalnog izvještaja ili u okviru integriranih izvještaja za poduzeća koja kotiraju na Zagrebačkoj burzi, Londonskoj burzi, Frankfurtskoj burzi, burzi u New Yorku, burzi u Johannesburgu i Tokijskoj burzi.

U skladu s ciljevima i svrhom, ovaj rad strukturiran je u više poglavlja. Nakon uvodnog dijela, u drugom poglavlju analiziraju se i sistematiziraju značaj i trendovi u korporativnom izvještavanju te se daje pregled prethodnih istraživanja vezano uz prednosti integriranog izvještavanja. U trećem poglavlju sistematiziraju se međunarodni okviri koji se mogu koristiti pri pripremi nefinancijskih informacija i sastavljanju nefinancijskih izvještaja, te se daje pregled nacionalnog zakonskog okvira u zemljama obuhvaćenim ovim istraživanjem. U četvrtom poglavlju prezentirani su rezultati provedene analize nefinancijskih izvještaja 
poduzeća koja kotiraju na Zagrebačkoj burzi i odabranim svjetskim burzama. U posljednjem, petom poglavlju izneseni su najvažniji zaključci ovog istraživanja.

\section{ZNAČAJ I TRENDOVI U KORPORATIVNOM IZVJEŠTAVANJU}

\subsection{Korporativno izvještavanje kao temelj komunikacije između poduzeća i korisnika}

Svrha korporativnog izvještavanja je pružanje informacija o poduzeću i jačanje komunikacije između poduzeća i zainteresiranih korisnika. Donedavno se korporativno izvještavanje svodilo uglavnom na objavljivanje financijskih informacija u godišnjim financijskim izvještajima, te se odnosilo na objavljivanje izvještaja o financijskom položaju (bilance), izvještaja o dobiti (i izvještaja o sveobuhvatnoj dobiti), izvještaja o novčanim tokovima, izvještaja o promjenama kapitala te bilješki uz financijske izvještaje. Svi ti financijski izvještaji prezentiraju informacije koje predstavljaju učinke prošlih poslovnih odluka menadžmenta i prošlih poslovnih događaja. Međutim, različiti stakeholderi zainteresirani su i za brojne druge informacije o poduzeću povrh financijskih informacija.

Svijest korisnika o okolišu, ekonomiji i društvu u cjelini postaje sve izraženija, stoga je njihovo glavno pitanje da li određeno poduzeće generira vrijednosti i bogatstvo samo za vlasnike, ili svojim poslovanjem poduzeće generira dodanu vrijednost za društvo, okoliš i ekonomiju u kojoj djeluje.

Pored istinitih i pouzdanih informacija o prošlim poslovnim događajima koji su nastali kao rezultat prošlih poslovnih odluka i koji se objavljuju u financijskim izvještajima, transparentnost bi trebala obuhvaćati i jasno prezentiranje strategije te budućih poslovnih inicijativa poduzeća. Nadalje, trendovi u izvještavanju nužno se prilagođavaju informatičkim trendovima i mogućnostima te se zahtijeva objavljivanje informacija na dnevnoj razini, umjesto objavljivanje informacija tek kad istekne obračunsko (izvještajno) razdoblje na koje se informacije odnose. Informacija mora biti odmah dostupna korisnicima kako bi imala dodanu vrijednost za donositelje poslovnih odluka i kako bi se odmah mogla implementirati u proces donošenja odluka.

Posljednjih desetljeća značajno se je promijenio fokus izvještavanja i objavljivanja, te je pri tome sve veći naglasak dan na kritična globalna pitanja kao što je na primjer pitanje klimatskih promjena, doprinosa poslovnih aktivnosti poboljšanju kvalitete življenja i ekosustava, te poslovnih učinaka diljem cjelovitog opskrbnog lanca (Global Reporting Initiative, 2016). Također, razvoj informatičke 
tehnologije ima ključnu ulogu u izvještavanju i analizi podataka. Korisnici žele informacije odmah i bez odgađanja, odnosno u realnom vremenu.

Financijska tržišta oslanjaju se na relevantne informacije koje su jasno i precizno prezentirane, tako da razumljivost i korisnost korporativnih izvještaja ima važnu ulogu u osiguravanju učinkovitog funkcioniranja i podrške ,zdravom“ gospodarstvu (KPMG, 2016). Stoga se može zaključiti da za dobivanje cjelovite slike o poslovanju poduzeća nisu dovoljne samo financijske informacije, već je nužna objava i nefinancijskih informacija kako bi se ocijenio potencijal poduzeća za rastom, dugoročnom održivošću te ostvarivanjem zarada i generiranjem novčanih tokova i u budućim razdobljima.

Kako su se mijenjale informacijske potrebe korisnika i okruženje u kojem poduzeća posluju, mijenjalo se i razvijalo korporativno izvještavanje, a njegov razvoj prikazan je na slici 1 .

Slika 1. Razvoj korporativnog izvještavanja

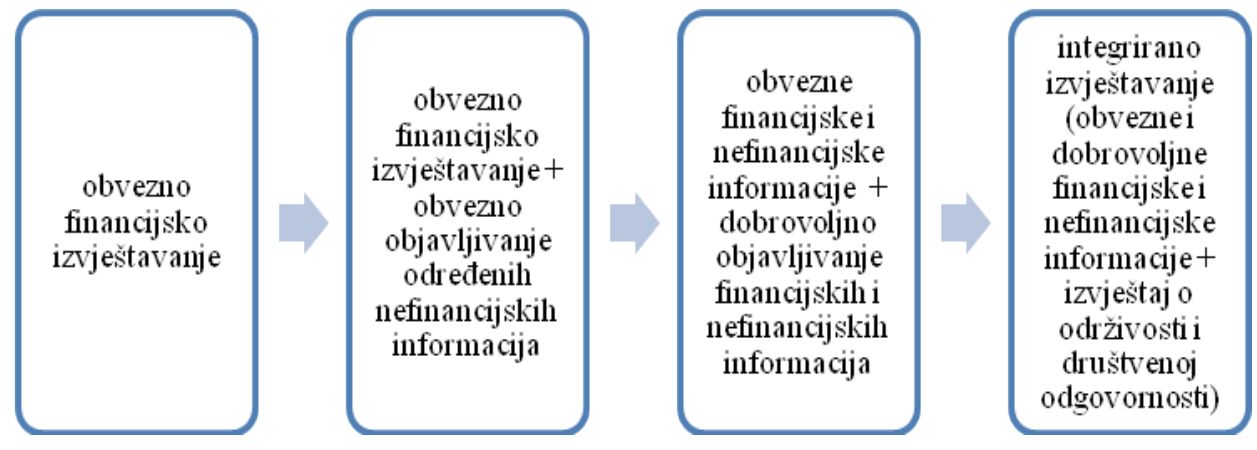

Izvor: Gulin, D., Grbavac, J., Hladika, M. (2016) Kvaliteta korporativnog izvještavanja kao pretpostavka transparentnosti poslovnih subjekata, Zbornik radova (Journal of Economy and Business), Posebno izdanje, str. 159.

Tijekom posljednjih tridesetak godina svijest o očuvanju okoliša, socijalnim, društvenim i ekonomskim pitanjima rapidno se povećavala. Uslijed toga, razvijen je i novi pristup korporativnom izvještavanju koji uvodi model integriranog izvještavanja. Kroz ovakav novi pristup korporativnom izvještavanju, poduzeća bi u svojim izvještajima pored financijskih informacija, trebala objavljivati i nefinancijske informacije čime bi se doprinijelo integriranom promišljanju i poboljšanju procesa upravljanja i korporativne odgovornosti. Korisnicima postaju sve interesantnije i potrebnije informacije kojima se dobiva šira slika o poslovanju poduzeća, a to su prije svega informacije o strategiji i viziji poduzeća, utjecaju aktivnosti poduzeća na društvo, okoliš i gospodarstvo u cjelini, načinu na koji 
poduzeće stvara dodanu vrijednost i slično. Takvi trendovi i promjene u izvještavanju i informacijskim potrebama zahtijevaju od menadžera njihovo razumijevanje i uvažavanje kako bi ih uspješno integrirali u poslovnu strategiju i u proces donošenja poslovnih odluka.

Dionici - stakeholderi s pravom očekuju da će današnja poduzeća zaštititi sve oblike kapitala - financijske, prirodne, ljudske, intelektualne i društvene koji u kontekstu korporativnog upravljanja nikada nisu bili važniji. Samo usvajanjem ovakvog pristupa može se usaditi povjerenje javnosti i pouzdanost koje su jako bitne za zdravlje globalne ekonomije (ACCA, 2017).

Naglasak je sve više na dvosmjernoj komunikaciji između poduzeća i korisnika informacija, što znači da bi poduzeća tj. njihov menadžment trebao ,slušati“ korisnike i njihove informacijske potrebe te im javno pružiti takve informacije. Da bi navedena komunikacija bila ispunjena, zahtijeva se prijelaz iz periodičnog statičnog izvještaja (godišnji financijski izvještaji) na tekuće izvještavanje o financijskom i nefinancijskom uspjehu i mogućnostima, ali i potencijalnim problemima, rizicima i propustima. Cilj promjena u korporativnom izvještavanju je uvođenje obveze sastavljanja integriranog izvještaja u kojem će se objavljivati financijske i nefinancijske informacije (informacije o okolišnom, društvenom i upravljačkom učinku poduzeća). Drugim riječima, cilj korporativnog izvještavanja je integracija financijskih i nefinancijskih informacija. Temeljem prethodnih istraživanja i iskustava izvodi se zaključak da je namjena integriranog izvještaja da zamijeni godišnje izvješće.

Implementacija procesa integriranog izvještavanja i sastavljanje integriranog izvještaja kao outputa tog procesa u fokus stavlja integrirano promišljanje. Za razumijevanje integriranog izvještaja zahtijeva se viša razina promišljanja, donošenja poslovnih odluka i procesa izvještavanja za razliku od ,površne“ usklađenosti s regulatornim zahtjevima za izradu sadašnjeg (aktualnog) korporativnog izvještaja (Stent, Dowler, 2015).

\subsection{Integrirano izvještavanje kao temelj za poboljšanje transparentnosti, povjerenja i jačanje ugleda poduzeća}

Integrirano izvještavanje omogućuje veću transparentnost poslovanja nekog poduzeća. Hutton (2004) vidi integrirani pristup korporativnom izvještavanju kao više od menadžerskog alata, već kao pristup kojim bi se povećala transparentnost poduzeća usklađivanjem očekivanja investitora s namjerama menadžmenta. Yongvanich i Guthrie (2006) sugeriraju da tradicionalno financijsko računovodstvo postaje izlišno. Oni procjenjuju da između 50\% i 90\% vrijednosti koju stvara poduzeće generira intelektualni kapital, a ne tradicionalna fizička imovina. 
Cohen i Simnett (2015) ističu da integrirano izvještavanje predstavlja sljedeći korak u razvoju korporativnog izvještavanja. Vezano uz potrebu implementacije integriranih izvještaja važno je naglasiti da takvi suvremeni trendovi u korporativnom izvještavanju zahtijevaju od poduzeća da održivi razvoj ugrade u svoju poslovnu strategiju, te bi se na taj način istaknula zaštita ekonomskih interesa svih sudionika i minimiziranje agresije na prirodne resurse (Laptes, Sofian, 2016). Dumitru i Jinga (2015) naglašavaju da je cilj integriranog izvještavanja preusmjeravanje naglaska $\mathrm{s}$ vrijednosti stvorene za dioničare $\mathrm{u}$ kratkom roku na vrijednosti stvorene za sve stakeholdere u dugom roku, podršku menadžerima u procesu donošenja odluka i jačanju organizacijske kulture.

Rezultati istraživanja Međunarodnog vijeća za integrirano izvještavanje ukazali su na sljedeće prednosti što ih donosi integrirano izvještavanje i objavljivanje integriranog izvještaja (IIRC, 2014):

- novo i bolje razumijevanje načina na koji se stvara ili uništava vrijednost

- s promjenom razumijevanja načina stvaranja vrijednosti, javljaju se i promjene $u$ donošenju poslovnih odluka

- poboljšana kvaliteta upravljačkih/menadžerskih informacija koje se koriste kao input za donošenje poslovnih odluka

- poboljšanje odnosa sa stakeholderima - objavljenje informacije u integriranom izvještaju omogućuju pružateljima kapitala bolje razumijevanje strategije poduzeća i njegovih dugoročnih ciljeva

- integrirano izvještavanje mijenja način korporativnog izvještavanja, ali i način na koji poduzeća rade i razmišljaju o tome što rade.

Integrirano izvještavanje veći naglasak stavlja na nefinancijske mjere i dokaze o naporima za integraciju financijskih i okolišnih, društvenih i upravljačkih metrika s ciljem da se što bolje razumije održivost poduzeća (Atkins, Maroun, 2015). Danas čak 95\% najvećih svjetskih poduzeća (G250) sastavlja i objavljuje nefinancijske izvještaje. Prednosti nefinancijskih izvještaja i izvještavanja o nefinancijskim aspektima poslovanja poduzeća su višestruke i brojne, a kao najvažnije navode se jačanje povjerenja investitora i ostalih dionika, stvaranje konkurentske prednosti, poboljšanje ugleda poduzeća, veća odanost i zadovoljstvo zaposlenika, a samim time i poboljšana učinkovitost zaposlenika, te lakši pristup kapitalu i jeftinije zaduživanje.

Općenito, veći naglasak stavljen je na nefinancijske mjere i dokaze o naporima za integraciju financijskih i okolišnih, društvenih i upravljačkih metrika kako bi se bolje razumjela društvena odgovornost i održivost poslovanja poduzeća. 


\section{MEĐUNARODNI I REGULATORNI OKVIR INTEGRIRANOG IZVJEŠTAVANJA}

\subsection{Međunarodni okviri za sastavljanje nefinancijskih izvještaja}

Prethodno je već istaknuto da integrirano izvještavanje predstavlja proces pripreme i sastavljanja financijskih i nefinancijskih izvještaja i njihovo objavljivanje u integriranom izvještaju. Financijsko izvještavanje je obvezno, regulirano i uređeno nacionalnim zakonodavstvom, te se za sastavljanje financijskih izvještaja primjenjuju Međunarodni standardi financijskog izvještavanja i/ili različiti nacionalni računovodstveni standardi.

Budući da na nacionalnoj i međunarodnoj razini ne postoji okvir koji je propisan kao obvezan za pripremu nefinancijskih informacija i sastavljanje nefinancijskih izvještaja, važno je istaknuti da u praksi postoje različiti pristupi i okviri za izradu nefinancijskih izvještaja. Relevantni međunarodni okviri za sastavljanje nefinancijskih izvještaja su:

- GRI standardi (GRI)

- Međunarodni okvir za pripremu integriranih izvještaja $(<\mathrm{IR}>)$

- Smjernice za multinacionalna društva Organizacije za ekonomsku suradnju i razvoj (OECD)

- Norma (ISO) 26000 Međunarodne organizacije za normizaciju

- Tripartitna deklaracija o načelima koja se odnose na multinacionalna društva i socijalnu politiku Međunarodne organizacije rada te

- Globalni sporazum Ujedinjenih naroda (UNGC).

Svi prethodno navedeni međunarodni okviri uređuju pripremu i objavljivanje nefinancijskih informacija u okviru nefinancijskog izvještaja. Standardizirani nefinancijski izvještaji, a samim time i integrirani izvještaji, još uvijek ne postoje. Međutim, najrašireniji okvir za nefinancijsko izvještavanje danas predstavljaju GRI standardi što ih je razvila Globalna inicijativa za izvještavanje koji predstavljaju najbolju svjetsku praksu u dijelu nefinancijskog izvještavanja poduzeća, i na taj način zadovoljavaju informacijske potrebe različitih donositelja odluka, investitora i tržišta u cjelini. Standardizacijom nefinancijskog izvještavanja omogućilo bi se uspoređivanje poduzeća po pitanjima koja se odnose na ekonomske, okolišne i društvene kriterije kako na nacionalnoj, tako i na međunarodnoj razini. 


\subsection{Regulatorni okvir za sastavljanje nefinancijskih izvještaja u promatranim zemljama}

Na broj poduzeća koja objavljuju nefinancijske izvještaje u velikoj mjeri utječe zakonska regulativa, odnosno činjenica je li zakonom propisana obveza sastavljanja nefinancijskih izvještaja ili se oni pripremaju na dobrovoljnoj osnovi. Također, moguće je da u određenoj zemlji burza propisuje zahtjeve na nefinancijskim izvještavanjem. U osam zemalja u kojima je stopa nefinancijskog izvještavanja 90\% ili više propisana je obveza nefinancijskog izvještavanja, a to su: Indija, Indonezija, Malezija, Južnoafrička Republika, Velika Britanija, Francuska, Danska i Norveška (KPMG, 2015).

U Južnoafričkoj Republici, Institut direktora donio je ,The third King Code of Governance Principles (King III)“ koji je stupio na snagu 1. ožujka 2010. godine u kojem su donesene preporuke koje su obvezna primjenjivati sva poduzeća, i po kojima su sva poduzeća u teoriji obvezna sastavljati samo integrirane izvještaje. U tom smislu, Južnoafrička Republika bila je prva zemlja koja je uvela obvezu sastavljanja i objavljivanja integriranih izvještaja za kotirana poduzeća kao odgovor na društvene, političke, okolišne i ekonomske izazove. Burza u Johannesburgu nastavila je promicati dobro korporativno upravljanje te je uključila obvezu sastavljanja integriranog izvještaja kao zahtjev za kotirana poduzeća i sukladno tome preko 400 poduzeća koja kotiraju na burzi u Johannesburgu dužna su objavljivati nefinancijske informacije unutar integriranih izvještaja na bazi „Primjeni ili objasni“. Odnosno, sva poduzeća su dužna objaviti integrirane izvještaje, a ukoliko ih ne objave moraju argumentirati zašto poduzeće nije sastavilo integrirani izvještaj. Međutim, većina poduzeća i dalje objavljuje odvojene nefinancijske izvještaje koji sadržavaju veći opseg informacija od informacija navedenih u integriranim izvještajima (Eccles, Schulschenk i Serafeim, 2012.)

U Sjedinjenim Američkim Državama nefinancijsko izvještavanje nije zakonom propisano kao obvezno, međutim većina poduzeća objavljuje nefinancijske izvještaje. 2011. godine osnovan je Odbor za računovodstvene standarde održivosti (engl. Sustainability Accounting Standards Board - SASB). SASB donosi i razvija računovodstvene standarde za 79 industrija, a standardi omogućuju poduzećima da jednostavnije objavljuju značajne i korisne informacije za sve dionike poduzeća (SASB).

Europska komisija je Direktivom 2014/95/EU zatražila od svih država članica Europske Unije da u svoje zakonodavstvo implementiraju nove zahtjeve po kojima određena poduzeća moraju sastavljati i nefinancijske izvještaje. Direktiva 2014/95/EU odnosi se na velika poduzeća i subjekte od javnog interesa koji na datum bilance prelaze kriterij prosječnog broja od 500 zaposlenih, a Direktivom 
2014/95/EU nefinancijsko izvještavanje postaje obvezno za obračunska razdoblja koja su počela 1. siječnja 2017. godine ili tijekom kalendarske 2017. godine.

U Japanu nefinancijsko izvještavanje nije zakonom propisano međutim velika većina poduzeća ipak objavljuje nefinancijske izvještaje, ali većinom u obliku odvojenih nefinancijskih izvještaja, dok je integrirano izvještavanje tek u začecima i mali broj poduzeća objavljuje integrirane izvještaje (Ryall, 2015).

\section{ANALIZA OBJAVLJENIH INTEGRIRANIH IZVJEŠTAJA NA ZAGREBAČKOJ BURZI I ODABRANIM SVJETSKIM BURZAMA}

Cilj ovog rada je istražiti da li i u kojoj mjeri kotirana poduzeća na Zagrebačkoj burzi i na odabranim svjetskim burzama objavljuju integrirane izvještaje te koji okvir za sastavljanje nefinancijskih izvještaja promatrana poduzeća koriste. Istraživanje se temelji na analizi izvještaja poduzeća unutar indeksa CROBEX10 ${ }^{1}$ koji je indeks Zagrebačke burze, FTSE100² koji je indeks Londonske burze, DAX30 ${ }^{3}$

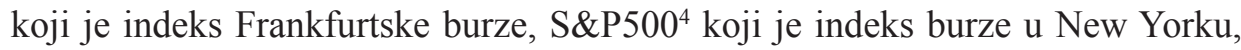
S\&P South Africa ${ }^{5}$ koji je indeks burze u Johannesburgu i NIKKEI2256 koji je indeks burze u Tokiju. Prethodno navedene međunarodne burze su odabrane jer predstavljaju najveće burze s obzirom na volumen trgovanja u pojedinim dijelovima svijeta (Europa, Sjeverna Amerika, Azija i Afrika).

U Tablici 1. navedene su burze koje su uključene u istraživački uzorak, njihovi burzovni indeksi i broj analiziranih poduzeća po pojedinoj burzi.

1 U CROBEX10 uključeno je 10 dionica iz sastava indeksa CROBEX s najvećom free-float tržišnom kapitalizacijom i prometom.

2 U FTSE100 uključeno je 100 dionica koje kotiraju na Londonskoj burzi s najvećom tržišnom kapitalizacijom.

3 Unutar indeksa DAX30 nalazi se 30 najvećih i najlikvidnijih poduzeća u Njemačkoj.

4 S\&P500 se sastoji od 500 tržišno najvrjednijih dioničkih društava čijim se dionicama aktivno trguje u Sjedinjenim Američkim Državama.

5 S\&P South Africa indeks se sastoji od dionica velikih, srednjih i malih poduzeća koja kotiraju na burzi u Johannesburgu. Indeks uključuje poduzeća iz Južnoafričke Republike i strana poduzeća sa sjedištem u Južnoafričkoj Republici.

6 NIKKEI225 je indeks u koji je uključeno 225 poduzeća iz Japana koji nose status Blue chip dionice (najbolje dionice). 
Tablica 1. Uzorak poduzeća

\begin{tabular}{|l|c|c|c|c|}
\hline \multicolumn{1}{|c|}{ Burza } & Indeks & $\begin{array}{c}\text { Broj po- } \\
\text { duzeća } \\
\text { uključenih u } \\
\text { indeks }\end{array}$ & $\begin{array}{c}\text { Broj analizi- } \\
\text { ranih podu- } \\
\text { zeća }\end{array}$ & $\begin{array}{c}\text { Postotak analizira- } \\
\text { nih poduzeća }\end{array}$ \\
\hline Zagrebačka burza & CROBEX10 & 10 & 10 & $100 \%$ \\
\hline Londonska burza & FTSE100 & 100 & 50 & $50 \%$ \\
\hline Frankfurtska burza & DAX30 & 30 & 30 & $100 \%$ \\
\hline Burza u New Yorku & S\&P 500 & 500 & 50 & $10 \%$ \\
\hline $\begin{array}{l}\text { Burza u Johannes- } \\
\text { burgu }\end{array}$ & $\begin{array}{c}\text { S\&P SOUTH } \\
\text { AFRICA }\end{array}$ & 10 & 10 & $100 \%$ \\
\hline Burza u Tokiju & NIKKEI225 & 225 & 50 & $22 \%$ \\
\hline
\end{tabular}

Izvor: obrada autora

Za burze čiji indeks uključuje manji broj poduzeća (Zagrebačka burza, Frankfurtska burza i burza u Johannesburgu) analizirana su sva poduzeća uključena u indeks. Za burze čiji indeks uključuje veći broj poduzeća (Londonska burza, burza u New Yorku i burza u Tokiju) slučajnim uzorkom odabrano je 50 poduzeća čiji su izvještaji analizirani iz cjelokupnog broja poduzeća u pojedinom indeksu. Sukladno broju promatranih poduzeća, uzorak za burzu u New Yorku obuhvaća 10\% ukupnog broja poduzeća u indeksu S\&P 500, dok je za burzu u Tokiju analizirano $22 \%$ poduzeća od ukupnog broja poduzeća uključenih u indeks Nikkei225. Kod analize izvještaja poduzeća na burzi u Tokiju pojavio se i problem jezične barijere jer značajan broj poduzeća objavljuje izvještaje samo na japanskom jeziku i ne objavljuje izvještaje na engleskom jeziku te je nastao problem kod analize stoga su u uzorak izabrana samo ona poduzeća koja objavljuju izvještaje na engleskom jeziku. Istraživanje se temeljilo na analizi nefinancijskih izvještaja koje poduzeća objavljuju na svojim internetskim stranicama ili su objavljeni unutar Baze izvještaja o održivosti (Global Reporting Initiative, 2017) za razdoblje od 2013. do 2015. godine. Istraživanjem je obuhvaćeno razdoblje od tri godine iz razloga nedostupnosti podataka iz ranijih razdoblja. Na temelju analize promatranih poduzeća zaključeno je kako su tek posljednjih nekoliko godina poduzeća počela objavljivati nefinancijske informacije u obliku izvještaja, dok su u samim počecima objavljivanja nefinancijskih informacija ti podaci bili većinom objavljeni samo na njihovim web stranicama kao obavijesti svim zainteresiranim dionicima o pojedinim područjima nefinancijskih informacija.

Istraživanjem je utvrđeno kako najviše poduzeća koja kotiraju na Frankfurtskoj burzi (DAX30) objavljuje nefinancijske izvještaje. U 2015. godini nefinancijske izvještaje objavilo je 97\% kotiranih poduzeća unutar indeksa DAX30, dok je najmanji broj objavljenih nefinancijskih izvještaja na burzi u New Yorku (indeks S\&P500) na kojoj je u 2015. godini nefinancijske izvještaje objavilo 62\% poduzeća. 
Grafikon 1. Postotak poduzeća koja objavljuju nefinancijske izvještaje

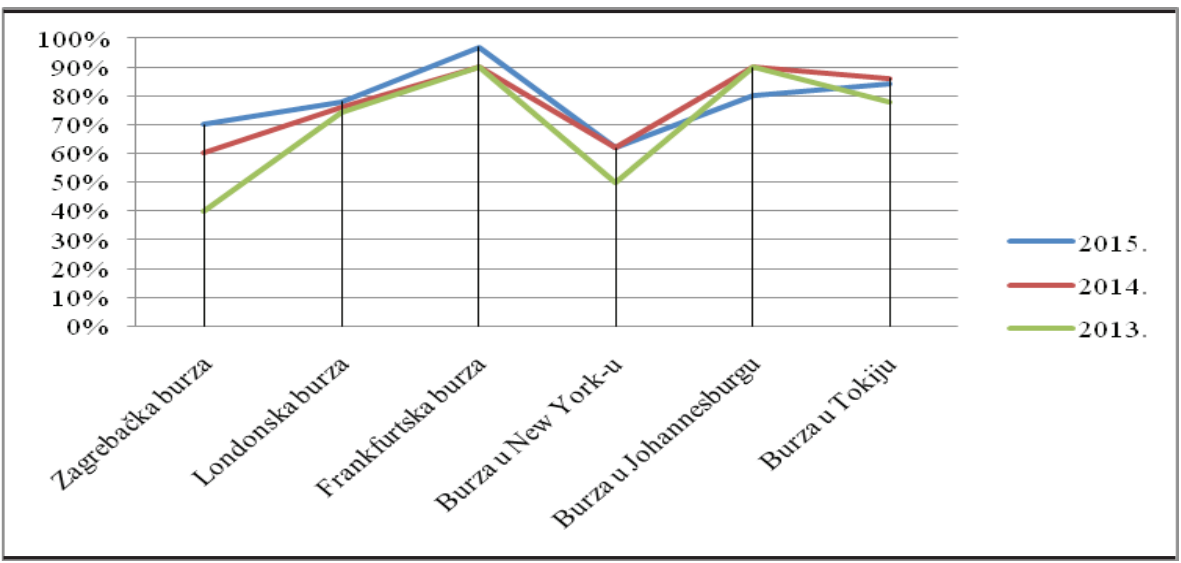

Izvor: obrada autora

Međutim, kroz promatrano razdoblje vidljiv je trend povećanja broja objavljenih nefinancijskih izvještaja na većini svjetskih burzi, a osobito na Frankfurtskoj i Zagrebačkoj burzi.

Prilikom objave nefinancijskih izvještaja svako poduzeće objavljuje izvještaj pod nazivom koji smatra najprikladnijim jer službeni naziv izvještaja nije definiran. Međutim, većina poduzeća koristi nazive slične Izvještaju o održivosti (Sustainability Report). U Tablici 2. navedeni su najčešće korišteni nazivi izvještaja u kojima se objavljuju nefinancijske informacije. 
Tablica 2. Nazivi izvještaja u kojima se objavljuju nefinancijske informacije

\begin{tabular}{|c|c|}
\hline Indeks & Naziv izvještaja \\
\hline CROBEX10 & $\begin{array}{c}\text { Izvještaj o održivosti } \\
\end{array}$ \\
& $\begin{array}{c}\text { Izvješće o društveno odgovornom poslovanju } \\
\text { Izvještaj o održivom razvoju }\end{array}$ \\
\hline FTSE100 & Corporate Responsibility Report \\
& Corporate Social Responsibility Report \\
& Sustainability Report \\
& Environmental Social Supplement \\
\hline DAX30 & Corporate Responsibility Report \\
& GRI Report \\
& Sustainability Report \\
\hline S\&P500 & Corporate Responsibility Report \\
& Corporate Citizenship Report \\
& Corporate Social Responsibility Report \\
& Sustainability Report \\
\hline DOW JONES SOUTH AFRICA & Sustainability Report \\
& Integrated Report \\
& Annual Report \\
& Sustainable Development Report \\
\hline NIKKEI225 & Corporate Social Responsibility Report \\
& Annual Report \\
& Sustainability Report \\
& Enviromental and Social Report \\
\hline
\end{tabular}

Izvor: obrada autora

Od ukupnog broja objavljenih nefinancijskih izvještaja, 2015. godine je nefinancijske informacije u obliku zasebnog izvještaja objavilo 84\% promatranih poduzeća, dok su ostala poduzeća nefinancijske informacije objavila unutar godišnjeg izvješća ili integriranog izvještaja. Iz Grafikona 2. je vidljivo kako je postotak poduzeća koja objavljuju nefinancijske informacije unutar godišnjeg izvješća ili integriranog izvještaja konstantan, ali još uvijek većina poduzeća objavljuje nefinancijske informacije kroz odvojene izvještaje. 
Grafikon 2. Način objave nefinancijskih informacija

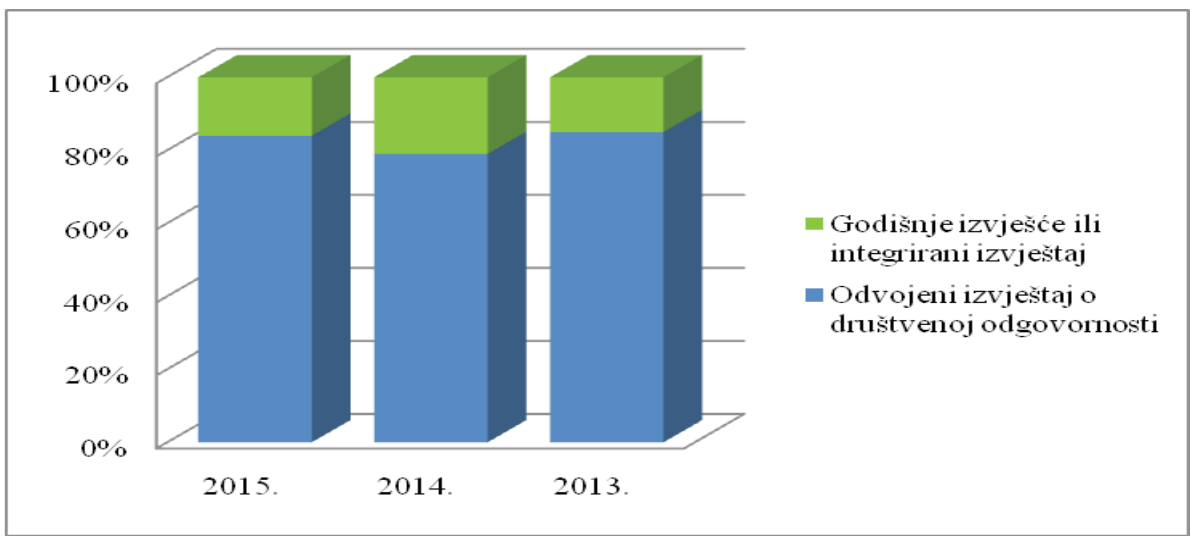

Izvor: obrada autora

Na Grafikonu 3. prikazani su načini objave nefinancijskih izvještaja po promatranim burzama, temeljem kojeg se može zaključiti kako sva poduzeća koja kotiraju na burzi u New Yorku objavljuju nefinancijske informacije u odvojenim izvještajima o društvenoj odgovornosti, dok poduzeća koja kotiraju na burzi u Johannesburgu objavljuju velikim dijelom nefinancijske informacije unutar godišnjeg izvješća ili integriranog izvještaja što je i očekivano zbog zakonske regulative kojom se od poduzeća zahtijeva da počnu objavljivati samo jedan izvještaj i to integrirani izvještaj, a ne pojedinačne financijske i nefinancijske izvještaje.

Grafikon 3. Način objave nefinancijskih informacija po burzama

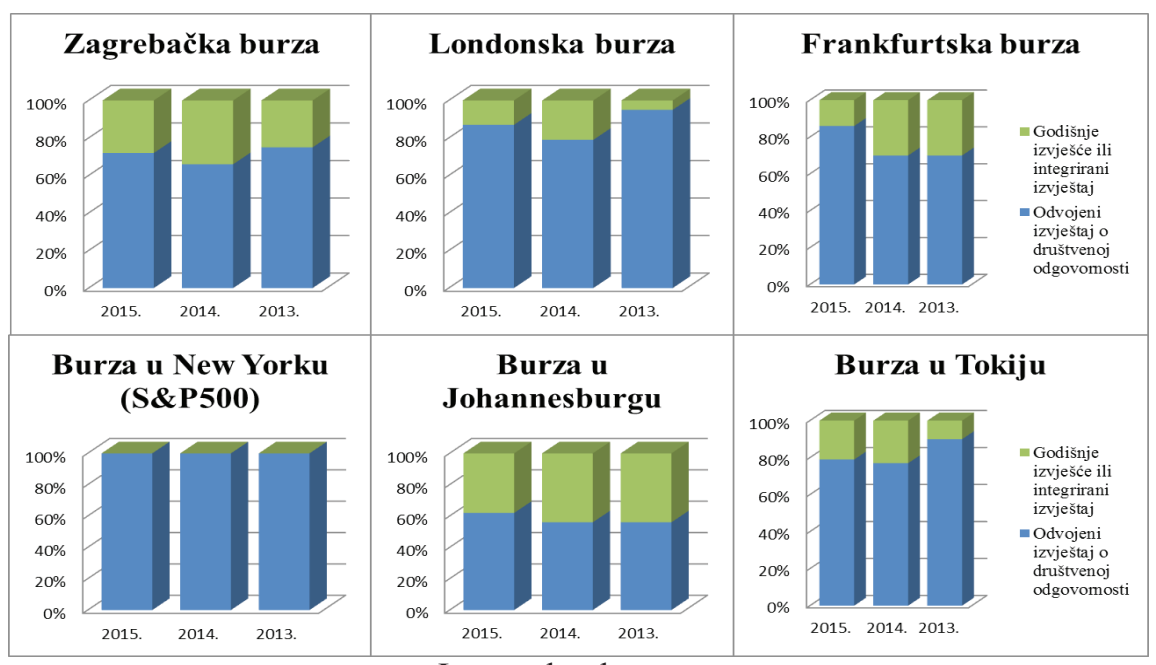

Izvor: obrada autora 
$\mathrm{Na}$ temelju provedenog istraživanja i rezultata prezentiranih u grafikonu 3. može se zaključiti kako velika većina poduzeća sastavlja zasebno nefinancijske izvještaje i financijske izvještaje. Razlog tome može biti u tome što poduzeća smatraju kako je korisnicima njihovih izvještaja jednostavnije pregledavati izvještaje ukoliko su objavljeni pojedinačno (tj. odvojeno), ili iz razloga što za godišnje financijske izvještaje imaju rokove objave dok nefinancijski izvještaji mogu biti objavljeni u bilo kojem razdoblju (roku) i najčešće su objavljeni nakon objave financijskih izvještaja. Također, mnoga poduzeća objavljuju svoje nefinancijske izvještaje samo na svojim web stranicama u obliku interaktivne web stranice gdje korisnik (dionik) može sam izabrati koje dijelove izvještaja želi vidjeti a pomoću interaktivne web stranice mu se omogućava da na zanimljiv način dobije uvid u poslovanje poduzeća.

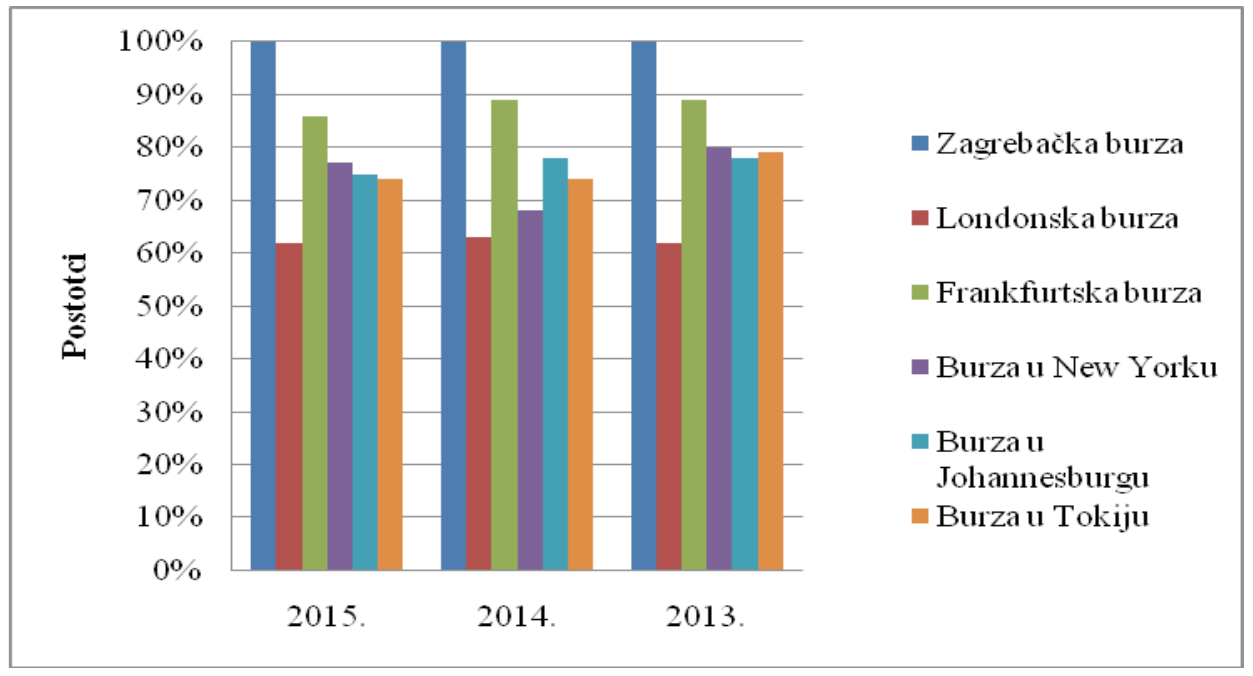

Izvor: obrada autora

Iz Grafikona 4. vidljivo je kako najveći postotak poduzeća koja kotiraju na Zagrebačkoj burzi sastavlja izvještaje u skladu s GRI smjernicama. Međutim, razlog tome je mali broj poduzeća koja se nalaze unutar indexa CROBEX10, i malog uzorka zbog čega su svi promatrani objavljeni nefinancijski izvještaji sastavljeni u skladu s GRI smjernicama. Najveći broj sastavljenih nefinancijskih izvještaja u skladu s GRI smjernicama je unutar promatranih izvještaja poduzeća na Frankfurtskoj burzi gdje preko $85 \%$ poduzeća sastavlja izvještaje u skladu s GRI smjernicama. Nakon toga slijede poduzeća koja kotiraju na burzi u Johannesburgu, New Yorku i Tokiju, dok najmanji broj poduzeća na Londonskoj burzi sastavlja izvještaje u skladu s GRI smjernicama. 
Na grafikonu 5. prikazana je analiza broja stranica objavljenih odvojenih nefinancijskih izvještaja za odabrana poduzeća na svjetskim burzama. Iako analiza broja stranica nije najbolji pokazatelj obuhvata objavljenih informacija jer poduzeća često na različite načine sastavljaju nefinancijske izvještaje koji mogu u velikoj mjeri utjecati na broj stranica i prividno inicijalno navesti na veći obuhvat informacija sadržanih u izvještaju, u nastavku je dana analiza broja stranica kao okvirni prikaz opsežnosti informacija. Tako se na temelju rezultata provedenog istraživanja može zaključiti kako najveći prosječni broj stranica imaju nefinancijski izvještaji objavljeni na Frankfurtskoj burzi na kojoj poduzeća prosječno objavljuju nefinancijske izvještaje od oko 100 stranica. Nakon toga slijedi Zagrebačka burza i burza u Tokiju na kojima nefinancijski izvještaji u prosjeku imaju više od 60 stranica.

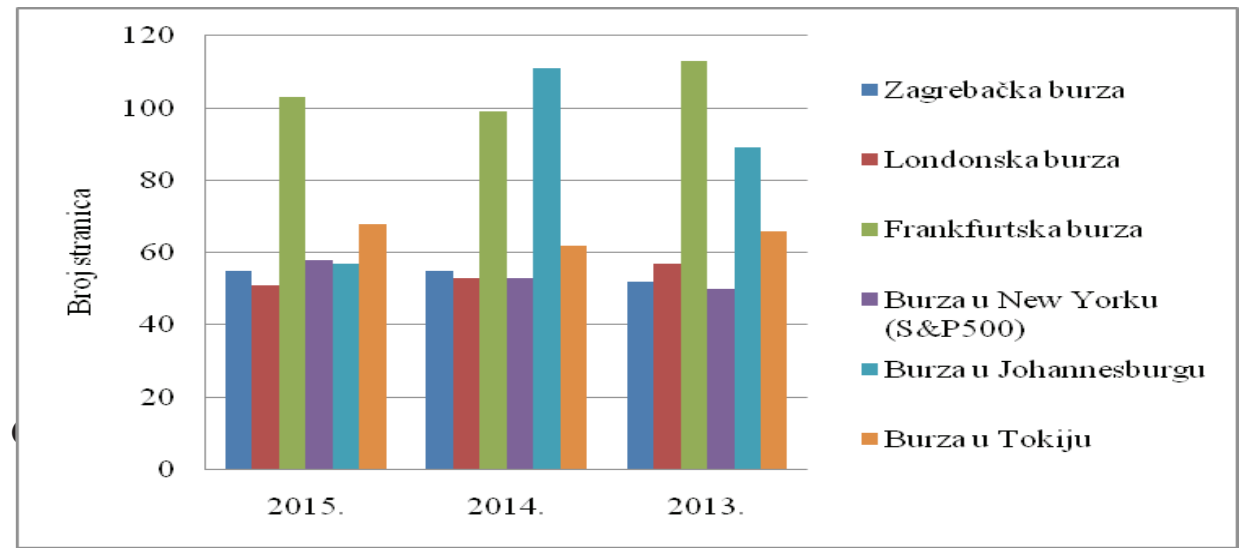

Izvor: obrada autora

Razlog zbog kojeg poduzeća na Frankfurtskoj i Tokijskoj burzi sastavljaju opsežnije nefinancijske izvještaje sadržan je u tome što je u tim zemljama kultura izvještavanja na visokoj razini, a putem dodatnih informacija u nefinancijskim izvještajima žele osigurati bolju i otvoreniju komunikaciju sa svim dionicima.

Na temelju provedenog istraživanja može se zaključiti kako poduzeća koja kotiraju na Frankfurtskoj, Tokijskoj i burzi u Johannesburgu objavljuju najveći broj nefinancijskih izvještaja, objavljuju najcjelovitije i najopsežnije izvještaje s ciljem što bolje komunikacije i suradnje sa svojim dionicima. Također, poduzeća s navedenih burzi sastavljaju velikom većinom svoje izvještaje na temelju GRI smjernica što samo potvrđuje visoki stupanj razvijenosti i financijskog tržišta i društvene odgovornosti poduzeća. Također, zaključuje se da još uvijek relativno mali broj poduzeća sastavlja i objavljuje integrirane izvještaje, ali razmatrajući trendove u financijskom izvještavanju za očekivati je da će se u skorom razdoblju njihov broj povećavati. 
U radu je dan općeniti pregled nefinancijskih izvještaja jer je zbog različitih načina objave nefinancijskih informacija teško unificirati i analizirati kvalitetu i sadržaj nefinancijskih izvještaja. Temeljno ograničenje rada je mali promatrani uzorak analiziranih poduzeća na velikim burzama. Međutim zbog nedostupnosti podataka na pojedinim burzama (jer svi izvještaji nisu javno dostupni te je teško doći do kompletnih financijskih i nefinancijskih izvještaja poduzeća) kao i barijere u jezicima, u uzorak su odabrani samo izvještaji na engleskom jeziku čime se uvelike umanjio sami uzorak poduzeća.

\section{ZAKLJUČAK}

Integrirano izvještavanje predstavlja novu praksu u korporativnom izvještavanju koja je još uvijek u fazi intenzivnog razvoja i implementacije na međunarodnoj razini. Integrirani izvještaj pruža informacije o načinu na koji poduzeće ostvaruje svoju viziju i strategiju promatrano s aspekta prošlih događaja, ali i perspektive u budućnosti, ukazuje na društvenu odgovornost poduzeća i perspektivu održivosti poslovanja poduzeća.

Objavljivanje nefinancijskih informacija bilo u obliku samostalnih izvještaja ili u okviru integriranog izvještaja značajno doprinosi transparentnosti, jačanju ugleda poduzeća i povećanju povjerenja u poslovanje poduzeća. Nefinancijskim izvještavanjem, a posebno njegovim objavljivanjem u okviru integriranog izvještaja, značajno se podiže kvaliteta korporativnog izvještavanja. Dodanu vrijednost nefinancijskog izvještavanja čini kvantificiranje učinaka poslovanja poduzeća na društvo, okoliš i ekonomiju u cjelini, a posljedično i utjecaj poslovanja poduzeća na održivi razvoj (Hladika, Valenta, 2017).

Rezultati provedenog istraživanja pokazuju rastući trend u nefinancijskom izvještavanju i to najčešće u obliku samostalnih izvještaja, dok je još uvijek evidentna nedostatna zastupljenost i izrada integriranih izvještaja izuzev u Južnoafričkoj Republici gdje je zakonom propisana obveza sastavljanja integriranih izvještaja za kotirana poduzeća. Kod poduzeća koja su uvela nefinancijsko izvještavanje kao komponentu korporativnog izvještavanja utvrđeno je da su ona u svoju poslovnu strategiju uvrstila ekonomske, okolišne i društvene aspekte poslovanja te da ona u nefinancijskim izvještajima kvantificiraju učinke svojih poslovnih odluka i aktivnosti na cjelokupnu ekonomiju, društvo i okoliš.

Da bi integrirani izvještaji bili korisni i razumljivi različitim stakeholderima, poželjno je da isti budu koncizni i sažeti s fokusom na ključne financijske i nefinancijske pokazatelje koji ukazuju na uspješnost, društvenu odgovornost i održivost poduzeća. Opravdano je očekivati da će uspostavljanje i implementacija učinkovitog sustava integriranog izvještavanja zahtijevati određeno vrijeme da 
se poduzeća uhvate s izazovima i promjenama u izvještajnom sustavu i kulturi izvještavanja, a neosporno je da će u cijelom tom procesu ključnu ulogu odigrati nacionalna zakonodavstva i regulativa koja uređuje korporativno izvještavanje, te zahtjevi burzi za izvještavanjem kotiranih poduzeća. Nastavno na navedeno, propisivanje obveze sastavljanja integriranog izvještaja i razvoj integriranog promišljanja s ciljem da se postigne bolja korporativna komunikacija između poduzeća i svih zainteresiranih stakeholdera zahtijeva suradnju ne samo poduzeća i stakeholdera, već i regulatora, donositelja standarda, revizora, računovođa, civilnog društva i svih ostalih sudionika poslovnih procesa koji su zainteresirani za korporativno izvještavanje.

Finalno, pored same činjenice da su poduzeća na globalnoj razini počela u sve većem broju i sve većoj mjeri objavljivati nefinancijske informacije, potrebno je razvijati i integrirano promišljanje što znači da stakeholderi moraju početi koristiti takve informacije $u$ donošenju strateških odluka. U budućim istraživanjima trebaju se detaljnije analizirati različiti načini objave nefinancijskih izvještaja te kao mjeru opsežnosti nefinancijskih izvještaja i njihove informativne snage za korisnike potrebno je istražiti broj i vrstu objavljenih nefinancijskih informacija, kao i druge pokazatelje. Također, u budućim istraživanjima trebalo bi istražiti ima li povećanje korporativne transparentnosti u vidu objave integriranih izvještaja ili pak odvojenih nefinancijskih i financijskih izvještaja značajniji utjecaj na profitabilnost poslovanja kotiranih poduzeća.

\section{LITERATURA}

1. ACCA (2017) Insights into Integrated Reporting. Dostupno na: http://www. accaglobal.com/content/dam/ACCA_Global/Technical/integrate/pi-insights-into-ir.pdf

2. Atkins, J., Maroun, W. (2015) Integrated Reporting in South Africa in 2012, Meditari Accountancy Research, Vol. 23, No. 2, pp. 197-221.

3. Cohen, J. R., Simnett, R. (2015) CSR and Assurance Services: A Research Agenda, Auditing: A Journal of Practice and Theory, Vol. 34, No. 1, pp. 49-74.

4. Couldridge, D. (2014) Investors and Integrated Reporting in South Africa. GAA Accounting, December 2014/January 2015. Dostupno na: http://www. gaaaccounting.com/investors-and-integrated-reporting-in-south-africa/

5. Direktiva 2014/95/EU o izmjeni Direktive 2013/34/EU u pogledu objavljivanja nefinancijskih informacija i informacija o raznolikosti određenih velikih poduzeća i grupa. Dostupno na: http://eur-lex.europa.eu/legal-content/HR/ TXT/PDF/?uri=CELEX:32014L0095\&from $=$ HR

6. Dumitru, M., Jinga, G. (2015) Integrated Reporting Practice for Sustainable Business, A Case Study, Audit Financiar, Vol. 13, Issue 127, pp. 117-125. 
7. Eccles, R. G., Schulschenk, J., Serafeim, G. (2012) Capturing the Link between Non-financial and Financial Performance in One Space. In: Making Investment Grade: The Future of Corporate Reporting, edited by van der Lugt, C. and Malan, D., str. 43-48.

8. Global Reporting Initiative (2016) The Next Era of Corporate Disclosure: Digital, Responsible, Interactive. Dostupno na: https://www.globalreporting. org/resourcelibrary/The-Next-Era-of-Corporate-Disclosure.pdf

9. Global Reporting Initiative (2017) Sustainability disclosure inititative. Dostupno na: http://database.globalreporting.org/

10. Gulin, D., Grbavac, J., Hladika, M. (2016) Kvaliteta korporativnog izvještavanja kao pretpostavka transparentnosti poslovnih subjekata, Zbornik radova (Journal of Economy and Business), Posebno izdanje, str. 154-180.

11. Hladika, M., Valenta, I. (2017) Nefinancijsko izvještavanje prema zahtjevima Direktive 2014/95/EU. Računovodstvo i financije, god. LXIII, broj 7, str. 39-44.

12. Hutton, A. (2004) Beyond financial reporting - an integrated approach to disclosure, Journal of Applied Corporate Finance, Vol. 16, No. 4, pp. 8-16.

13. IIRC (2014) Realizing the benefits: The impact of Integrated Reporting, Black Sun Plc. Dostupno na: http://integratedreporting.org/wp-content/uploads/2014/09/IIRC.Black_.Sun_.Research.IR_.Impact.Single.pages.18.9.14. pdfKPMG (2015) Currents of change - The KPMG Survey of Corporate Responsibility Reporting 2015. Dostupno na: https://home.kpmg.com/content/dam/kpmg/pdf/2015/12/KPMG-survey-of-CR-reporting-2015.pdf

14. KPMG (2016) Room for improvement - The KPMG Survey on Business Reporting, 2nd edition. Dostupno na: https://assets.kpmg.com/content/dam/ kpmg/pdf/2016/06/Room-for-improvement.pdf

15. Laptes, R., Sofian, I. (2016) A new dimension of the entities' financial reporting: Integrated Reporting, Bulletin of the Transilvania University of Brasov, Series V: Economic Sciences, Vol. 9(58), No. 2, pp. 239-250.

16. Ryall, J. (2015). Japan overhauls how companies communicate their progress. AB Magazine. URL: http://www.accaglobal.com/uk/en/member/member/ accounting-business/corporate/japan-ir.html

17. Stent, W., Dowler, T. (2015) Early assessments of the gap between integrated reporting and current corporate reporting, Meditari Accountancy Research, Vol. 23, No. 1, 92-117.

18. Sustainability Accounting Standards Board (SASB). URL: https://www.sasb. org/sasb/vision-mission/\#1470330074770-cc5dfde1-1eec

19. Yongvanich, K., Guthrie, J. (2006) An extended performance reporting framework for social and environmental accounting, Business Strategy and the Environment, Vol. 15, No. 5, pp. 309-321. 


\title{
Mirjana Hladika, Ph.D.
}

Faculty of Economics and Business, University of Zagreb, Croatia mhladika@efzg.hr

\section{Ivana Valenta, mag.oec.}

Faculty of Economics and Business, University of Zagreb, Croatia ivalenta@efzg.hr

\section{INTEGRATED REPORTING - NEW PLATFORM OF CORPORATE REPORTING}

\author{
Review
}

\begin{abstract}
Today, the market is continuously and rapidly progressing and changing. Awareness of social responsibility, environmental protection and human rights is becoming ever greater and more pronounced. Information technology is rapidly developing; climate changes and their effects are evident. Such trends in contemporary market have triggered changes in corporate reporting. The importance and significance of integrated reporting by comparison with traditional financial reporting is increasingly emphasized. The information needs of investors, creditors and other interest groups for the purpose of making business decisions, primarily investment and financing decisions exceed the financial information presented in the financial statements. In order to different stakeholders could evaluate business operations, they need different information to get a wider picture of business operations. Financial statements provide information on the financial position, financial performance and cash flows of the company that are the result of past business decisions and relate to past periods. Investors require information which will be useful for assessing the company's earnings and cash flows in the future period or periods. Such estimates are possible if investors have information about the company's business model, strategy and risks to which the company is exposed and the way it is managed. Based on this information, stakeholders are able to estimate the company's capacity to create sustainable value in the short, medium and long term, or how the company will generate sustainable value in the business environment in which it operates. By publishing of nonfinancial information, together with financial information, the company's transparency is strengthened and users gain a higher level of confidence in the business and the perspectives of such companies. Today, such nonfinancial information is being published coherently in integrated reports along with financial information. The purpose and aim of this paper is to investigate whether and to what extent the listed companies on the Zagreb Stock Exchange and on the selected world stock
\end{abstract}


exchanges publish integrated reports. In addition, the objective is to explore which framework is used for the preparation of nonfinancial statements.

Keywords: integrated reporting, corporate transparency, sustainable value, social responsibility

JEL: M40, M41 